\title{
URGENSI PEMBENTUKAN LEMBAGA MEDIASI PERBANKAN INDEPENDEN SEBAGAI UPAYA STRATEGIS MEWUJUDKAN ARSITEKTUR PERBANKAN
}

\author{
Ayu Denis Christinawati ${ }^{*}$ \\ ${ }^{1}$ Program Studi Akuntansi, STIE Al-Anwar, Mojokerto \\ Jalan Raya Brangkal No.70, Kedung Maling 3, Kecamatan Sooko, Mojokerto \\ *Correponding Author: ayudenis8@gmail.com
}

\begin{abstract}
The business world in Indonesia is growing rapidly, marked by the number of commercial banks and conventional banks. This development is accompanied by various problems that arise from customers to banks in payment systems and services. In this condition, the bank and the customer use mediation as an alternative solution for dispute resolution between the two parties. Banking mediation is an Indonesian Banking Architecture Program (API). This program is focused on efforts to empower and improve banking consumer protection. Seeing the importance of the complexity of the problems above, research is compiled which is expected to be able to provide and offer solutions to encourage the creation of a healthy and strong Indonesian Banking Architecture (API) in the future. What is the basis for the urgency of establishing an independent banking mediation institution? What is a concrete solution regarding the establishment of an independent banking mediation institution by the Banking Association as a strategic effort to realize the pillars of the Indonesian Banking Architecture (API)? In this study using the Normative Juridical research method. In this context the researcher wants to study and analyze several positive legal instruments that support (support) the implementation of dispute resolution mechanisms through the mediation process in the banking business sector. Besides examining positive legal instruments to complete the analysis, it also uses supporting data in the form of banking mediation practices implemented by Bank Indonesia and several banks. The urgency of establishing a banking mediation institution in an effort to realize the Independent Banking Architecture (API) is based on two aspects, namely the economic aspect and the juridical aspect. The establishment of a banking mediation institution must be encouraged by the banking association. So that there is no access to state losses that are charged. This happened because there was a dispute settlement between the banking and the customer mediated by Bank Indonesia.
\end{abstract}

Keyword: mediation, banking, bank, law. 


\begin{abstract}
ABSTRAK
Dunia bisnis di Indonesia berkembang pesat, ditandai dengan banyaknya bank umum dan bank konvensional. Perkembangan ini diiringi dengan berbagai permasalahan yang timbul dari nasabah kepada bank pada sistem pembayaran dan layanan. Pada kondisi ini, pihak bank dan pihak nasabah menggunakan mediasi sebagai alternatif solusi penyelesaian sengketa diantara kedua pihak. Mediasi perbankan adalah program Arsitektur Perbankan Indonesia (API). Program ini difokuskan pada upaya pemberdayaan dan peningkatan perlindungan konsumen perbankan. Melihat pentingnya kompleksitas permasalahan di atas maka disusun penelitian yang diharapkan mampu memberikan dan menawarkan solusi untuk mendorong terciptanya Arsitektur Perbankan Indonesia (API) yang sehat dan kuat di masa yang akan datang. Apa yang menjadi landasan urgensi pembentukan lembaga mediasi perbankan independen? Bagaimana solusi konkret mengenai pembentukan lembaga mediasi perbankan independen oleh Asosiasi Perbankan sebagai upaya strategis mewujudkan pilar Arsitektur Perbankan Indonesia (API)? Penelitian ini menggunakan metode penelitian Yuridis Normatif. Pada konteks ini peneliti ingin mengkaji dan menganalisis beberapa instrumen hukum positif yang mendukung (support) terhadap pelaksanaan mekanisme penyelesaian sengketa melalui proses mediasi di sektor bisnis perbankan. Selain meneliti instrumen hukum positif untuk melengkapi analisis, juga menggunakan data pendukung berupa praktik mediasi perbankan yang dijalankan oleh Bank Indonesia dan beberapa bank. Urgensi pembentukan lembaga mediasi perbankan dalam upaya mewujudkan Arsitektur Perbankan Independen (API) dilandasi oleh dua aspek yaitu aspek ekonomis dan aspek yuridis. Pembentukan lembaga mediasi perbankan harus didorong oleh asosiasi perbankan. Sehingga tidak ada akses kerugian negara yang dibebankan. Ini terjadi karena ada penyelesaian sengketa antara perbankan dan nasabah yang di mediatori oleh Bank Indonesia.
\end{abstract}

Kata kunci: mediasi, perbankan, bank, hukum.

\title{
PENDAHULUAN
}

Perkembangan bisnis perbankan di Indonesia berjalan sangat pesat. Hal ini ditandai dengan semakin banyaknya jumlah bank yang ada di Indonesia baik berupa bank umum maupun bank konvensial yang beroperasi berdasarkan prinsip Syari'ah semisal Bank BNI/BNI Syaria'h, Bank BRI, Bank Mandiri/Bank Mandiri Syari'ah, kemudian Bank Perkreditan Rakyat BPR dan berbagai jenis bank yang lainnya. Akan tetapi seiring dengan pesatnya perkembangan dunia perbankan diikuti juga dengan berbagai kompleksitas permasalahan yang dihadapi oleh bank terkait dengan adanya pengaduan nasabah kepada bank yang bersangkutan. Pengaduan yang dilakukan oleh pihak nasabah terkait dengan permasalahan-permasalahan yang menyangkut sistem pembayaran dan layanan jasa perbankan. Dalam hal ini baik pihak bank maupun pihak nasabah cenderung menggunakan mediasi sebagai alternatif solusi penyelesaian sengketa di antara ke dua belah pihak. 
Oleh sebab itu mediasi sebagai penyelesaian sengketa terkait dengan pengaduan nasabah lebih sering dipakai oleh pihak bank daripada proses litigasi ke pengadilan. Berdasarkan laporan bank umum kepada Bank Indonesia, pada triwulan I - 2007, jumlah pengaduan nasabah bank umum tercatat sebanyak 79.322 pengaduan. Dari jumlah itu 97,56\% merupakan permasalahan yang terkait dengan produk atau jasa pada sistem penyaluran dana, sistem pembayaran yang mencakup ATM, Kartu Debit, dan Kartu Kredit, penipuan melalui SMS, kesalahan transfer dan phone banking. Upaya-upaya yang menyeluruh pada percepatan proses mediasi perbankan, melalui peningkatan peran dan fungsi compliance dan pengawasan menjadi sangat penting. Mekanisme penyelesaian sengketa antara nasabah dan bank ditempuh melalui 2 (dua) tahap. Tahap pertama, bank wajib menyelesaikan terlebih dahulu sengketa dengan nasabahnya sesuai Peraturan Bank Indonesia Nomor 7/7/PBI/2005 tentang Penyelesaian Pengaduan Nasabah yang mana Bank Indonesia mewajibkan bank memberi jawaban lisan maupun tertulis. Tahap kedua, apabila sengketa belum dapat diselesaikan dengan baik, nasabah bank dapat mengajukan permohonan penyelesaian sengketa melalui mediasi yang difasilitasi Bank Indonesia sesuai Peraturan Bank Indonesia Nomor 8/5/PBI/2006 tentang Mediasi Perbankan. Adapun data yang dapat dipakai sebagai perbandingan mengenai jumlah pengaduan nasabah kepada bank yang terjadi didaerah Surabaya maupun yang ditangani oleh pihak Bank Indonesia adalah sebagai berikut:

Tabel 1

Jumlah Pengaduan Nasabah Kepada Bank

\begin{tabular}{|c|l|l|}
\hline No & Tahun (triwulan) & Jumlah Pengaduan \\
\hline 1 & Triwulan IV 2005 & 86.451 pengaduan \\
\hline 2 & Triwulan I 2006 & 71.816 pengaduan \\
\hline 3 & Triwulan II 2006 & 66.145 pengaduan \\
\hline 4 & Triwulan I 2007 & 79.322 pengaduan \\
\hline
\end{tabular}

Sumber: www.jatim.go.id

Berdasarkan tabel di atas dari jumlah pengaduan 66.145 pada triwulan ke II tahun 2006 sebesar 85\% pengaduan karena sistem pembayaran. Dengan rincian yang berkaitan dengan penyaluran dana 1.298 pengaduan, penghimpunan dana 814 pengaduan, dan produk kerjasama lain 226 pengaduan. Beberapa di antaranya dapat diselesaikan oleh pihak bank sendiri tanpa campur tangan Bank Indonesia. Sedangkan pada triwulan ke I tahun 2007 sebanyak 79.322 pengaduan. Dari jumlah itu 97,56\% merupakan permasalahan yang terkait dengan produk atau jasa pada sistem pembayaran yang mencakup ATM, Kartu Debit, dan Kartu Kredit. Sementara itu data dari Bank Indonesia menyebutkan bahwa, penyelenggaraan mediasi perbankan memang diperlukan. Data terakhir Bank Indonesia menyebutkan, penanganan kasus mediasi sejak Januari-Juni 2008 adalah 158 
kasus. Dari jumlah tersebut sebanyak 89 kasus selesai tanpa mediasi, 60 kasus sedang diproses, 6 kasus diselesaikan oleh bank dan 3 kasus diselesaikan lewat mediasi.

Tabel 2

Kasus Mediasi Perbankan

\begin{tabular}{|l|c|c|}
\hline \multirow{2}{*}{\multicolumn{1}{|c|}{ Jenis produk }} & \multicolumn{2}{c|}{ Total } \\
& Pengaduan/Permohonan \\
\cline { 2 - 3 } & Triwulan I & Triwulan II \\
\hline Penghimpunan dana & 14 & 12 \\
\hline Penyaluran dana & 23 & 43 \\
\hline Sistem pembayaran & 30 & 11 \\
\hline Produk kerjasama & 0 & 0 \\
\hline Produk lainnya & 2 & 3 \\
\hline $\begin{array}{l}\text { Diluar permasalahan } \\
\text { produk perbankan }\end{array}$ & 3 & 17 \\
\hline Total & $\mathbf{7 2}$ & $\mathbf{8 6}$ \\
\hline
\end{tabular}

Sumber: Bank Indonesia

Melihat kondisi yang ada dapat diketahui bahwa kompleksitas masalah perbankan terkait dengan pengaduan nasabah merupakan realita yang harus diselesaikan demi terwujudnya sistem perbankan yang mantap dan kuat di masa yang akan datang. Penyelesaian sengketa melalui jalur mediasi merupakan solusi alternatif untuk mengatasi kompleksitas yang ada terkait dengan pengaduan nasabah. Sebagai perbandingan bahwa negara-negara maju seperti Amerika Serikat dan Singapura menerapkan alternatif penyelesaian sengketa (APS) baik melalui mekanisme negosiasi, mediasi, maupun arbitrase dalam menyelesaikan masalah-masalah yang berkaitan dengan hal-hal yang besifat keperdataan.

Mengingat kebutuhan nasabah untuk melakukan upaya mediasi sebagai sarana penyelesaian sengketa dengan bank terus meningkat, khususnya di akhir dan awal semester, maka perlu membentuk lembaga mediasi independen. Mediasi perbankan merupakan salah satu program Arsitektur Perbankan Indonesia (API). Program ini difokuskan pada upaya pemberdayaan dan peningkatan perlindungan konsumen perbankan. Proses penyelesaian melalui mediasi perbankan ini selain bermanfaat bagi nasabah bank, juga akan menguntungkan bank. Karena melalui mediasi, sengketa perdata dengan nasabah lebih cepat diselesaikan. Hal ini diharapkan mempunyai dampak positif bagi kepuasan nasabah, meningkatkan kepercayaan nasabah sekaligus membantu pengelolaan risiko reputasi bank yang bersangkutan.

Akan tetapi pembentukan lembaga mediasai perbankan independen oleh asosiasi perbankan ini terkendala dari aspek normatif mengingat berdasarkan Peraturan Bank Indonesia terdapat keharusan dari Asosiasi Perbankan untuk secepatnya membentuk lembaga mediasi perbankan sampai tanggal 31 Desember 
2007 akan tetapi pada peraturan Bank Indonesia yang baru ketentuan pasal tersebut dihapuskan sehingga konsekuensinya untuk sementara waktu pelaksanaan mediasi dilakukan di bawah otoritas Bank Indonesia. Berdasarkan hal tersebut jelas bahwa ada sebuah itikad tidak baik dari pihak pengusaha perbankan untuk secepatnya membentuk lembaga mediasi perbankan. Sehingga secara riil indikasi yang timbul adalah pengusaha perbankan yang beroperasi dan memperoleh keuntungan, akan tetapi pihak Bank Indonesia yang harus menyelesaikan sengketa pengaduan nasabah jika terdapat sengketa antara bank dan nasabah yang total saldonya mencapai Rp. 500.000.000,- (lima ratus juta rupiah). Dengan diperankannya fungi mediasi oleh Bank Indonesia konsekuensi yang timbul adalah terserapnya Anggaran Pendapatan dan Belanja Negara (APBN) untuk menyelesaikan pengaduan nasabah yang seharusnya menjadi tanggung jawab pengusaha perbankan.

Mengingat begitu pentingnya kompleksitas permasalahan di atas, maka disusunlah sebuah penelitian yang diharapkan mampu memberikan dan menawarkan sebuah solusi konkret dalam rangka mendorong terciptanya Arsitektur Perbankan Indonesia (API) yang sehat dan kuat di masa yang akan datang. Berdasarkan uraian di atas, maka ada beberapa hal yang akan dibahas dalam penelitian ini, yaitu apa yang menjadi landasan urgensi pembentukan lembaga mediasi perbankan independen serta bagaimana solusi konret mengenai pembentukan lembaga mediasi perbankan independen oleh Asosiai Perbankan sebagai upaya strategis mewujudkan pilar Arsitektur Perbankan Indonesia (API).

\section{TINJAUAN PUSTAKA}

Menurut Ruru (2007) mediasi merupakan cara penyelesaian sengketa melalui perundingan di antara para pihak dengan bantuan pihak ketiga yang netral dan independen, yang disebut mediator, dengan tujuan tercapainya kesepakatan damai dari pihak bersengketa. Mediator hanya bertindak sebagai fasilitator pertemuan dan tidak memberikan keputusan atas sengketa. Para pihak sendiri yang memegang kendali dan menentukan hasil akhirnya, apakah akan berhasil mencapai perdamaian atau tidak. Sedangkan Peraturan Bank Indonesia Nomor 8/5/PBI/2006 tentang Mediasi Perbankan menyatakan bahwa mediasi adalah proses penyelesaian sengketa yang melibatkan mediator untuk membantu para pihak yang bersengketa guna mencapai penyelesaian dalam bentuk kesepakatan sukarela terhadap sebagian atau seluruh permasalahan yang disengketakan.

Mediasi sebagai salah satu mekanisme penyelesaian sengketa alternatif di luar pengadilan sudah lama dipakai dalam berbagai kasus-kasus bisnis, lingkungan hidup perburuhan, pertanahan, perumahan, sengketa konsumen, dan sebagainya yang merupakan perwujudan tuntutan masyarakat atas penyelesaian sengketa yang cepat, efektif, dan efisien. Mediasi berasal dari bahasa Inggris, "mediation" atau penengahan yaitu penyelesaian sengketa yang melibatkan pihak ketiga sebagai penengah atau penyelesaian sengketa secara menengahi.

Dengan demikian pada prinsipnya mediasi adalah cara penyelesaian sengketa di luar pengadilan melalui perundingan yang melibatkan pihak ketiga yang bersifat netral (non intervensi) dan tidak berpihak (imparsial), serta diterima kehadirannya oleh pihak-pihak yang bersengketa. Pihak ketiga tersebut disebut 
mediator atau penengah yang tugasnya membantu pihak-pihak yang bersengketa dalam menyelesaikan masalahnya, tetapi tidak mempunyai kewenangan untuk mengambil keputusan. Dengan mediasi diharapkan mencapai titik temu dalam menyelesaikan masalah yang dihadapi para pihak yang selanjutnya akan dituangkan dalam kesepakatan bersama. Pengambilan keputusan tidak berada di tangan mediator tetapi di tangan para pihak yang bersengketa. Pengertian mengenai mediasi yang lain adalah (i) pertama, mediasi adalah cara penyelesaian sengketa melalui perundingan di antara para pihak dengan bantuan pihak ketiga yang netral dan independen, yang disebut mediator, dengan tujuan tercapainya kesepakatan damai dari pihak bersengketa. Mediator hanya bertindak sebagai fasilitator pertemuan dan tidak memberikan keputusan atas sengketa. Para pihak sendiri yang memegang kendali dan menentukan hasil akhirnya, apakah akan berhasil mencapai perdamaian atau tidak (Ruru, 2007); (ii) kedua, mediasi adalah proses penyelesaian sengketa yang melibatkan mediator untuk membantu para pihak yang bersengketa guna mencapai penyelesaian dalam bentuk kesepakatan sukarela terhadap sebagian atau seluruh permasalahan yang disengketakan (Peraturan Bank Indonesia Nomor 8/5/PBI/2006 tentang Mediasi Perbankan pasal 1 ayat (5)); (iii) ketiga, mediasi adalah penyelesaian sengketa melalui proses perundingan para pihak dengan dibantu oleh mediator (Peraturan Mahkamah Agung (PERMA) Nomor 2 Tahun 2003 tentang Prosedur Mediasi di Pengadilan Mahkamah Agung Republik Indonesia pasal 1 ayat (6)).

Menurut Rachagan (2008) ada beberapa prinsip yang mesti harus dipenuhi dalam pengelolaan lembaga penyelesaian sengketa konsumen: (i) aksesibilitas yakni bagaimana mengupayakan agar lembaga penyelesaian sengketa konsumen dapat diakses seluas-luasnya oleh masyarakat. Prinsip ini meliputi elemen-elemen seperti: biaya murah, prosedur yang sederhana dan mudah, pembuktian yang fleksibel, bersifat komprehensif, mudah diakses langsung, dan tersosialisasi serta tersedia di berbagai tempat; (ii) fairness dalam arti keadilan lebih diutamakan daripada kepastian hukum sehingga sebuah lembaga penyelesaian sengketa konsumen setidaknya harus bersifat mandiri (independent) dan dapat dipertanggungjawabkan pada masyarakat (public accountability); (iii) efektif, sehingga lembaga penyelesaian sengketa harus dibatasi cakupan perkaranya (kompleksitas dan nilai klaim) dan setiap perkara yang masuk harus diproses secepat mungkin tanpa mengabaikan kualitas penanganan perkara. Untuk dapat dijalankannya prinsip-prinsip tersebut maka cara penyelesaian sengketa dengan pendekatan hukum yang legal-positivistik harus diubah dengan pendekatan hukum yang lebih kritis, responsif atau progresif. Secara singkat paradigma hukum progresif bertumpu pada filosofi dasarnya yakni: "hukum untuk manusia" yang dimaknai bahwa sistem manusia (sikap; perilaku) berada di atas sistem formal (aturan; keputusan administratif; prosedur; birokrasi). Dengan demikian bila sistem formal tidak bisa mewujudkan cara penyelesaian konsumen yang utuh, efektif dan adil atau memuaskan para pihak, maka sistem manusia harus mampu mewujudkan sendiri.

Bank sebagai lembaga keuangan memiliki definisi yang cukup luas dalam perkembangannya. Secara harfiah, menurut Departemen P dan K (1989) kata "bank" memiliki arti sebagai suatu lembaga keuangan yang usaha pokoknya 
memberikan kredit dan jasa dalam lalu lintas pembayaran dan peredaran uang. Pengertian bank ini diatur juga dalam pasal 1 Undang-Undang Nomor 10 tahun 1998 tentang Perubahan Undang-Undang Nomor 7 tahun 1992 tentang Perbankan, yang menyatakan bahwa bank adalah badan usaha yang menghimpun dana dari masyarakat dalam bentuk simpanan dan menyalurkannya kepada masyarakat dalam bentuk kredit dan atau bentuk lain dalam rangka meningkatkan taraf hidup rakyat banyak. Pengertian bank berasal dari Simorangkir (1986: 25) bank merupakan salah satu badan usaha lembaga keuangan yang bertujuan memberikan kredit dan jasa-jasa.

Di Indonesia lembaga keuangan bank mempunyai misi, dan fungsi yang khusus dan cukup luas, oleh karena bank merupakan alat pemerintah untuk menjaga stabilitas ekonomi moneter dan keuangan (Sumarni dan Soeprihanto, 1998: 113). Berdasarkan atas Undang-Undang Nomor 7 tahun 1992, jenis bank dibedakan menjadi dua, yaitu Bank Umum dan Bank Perkreditan Rakyat. Bank Umum adalah bank yang dapat memberikan jasa dalam lalu lintas pembayaran. Sedangkan Bank Perkreditan Rakyat adalah bank yang menerima simpanan hanya dalam bentuk deposito berjangka, tabungan, dan bentuk lainnya yang dipersamakan dengan itu. Bank Umum terdiri atas bank umum pemerintah, bank umum swasta, bank umum asing, dan bank umum koperasi. Bank Umum pemerintah terdiri dari Bank Nasional Indonesia 1946, Bank Dagang Negara, Bank Bumi Daya, Bank Rakyat Indonesia, dan Bank Ekspor Impor Indonesia. Berdasarkan atas ketentuan yang terdapat dalam Undang-Undang Nomor 10 tahun 1998, jasa yang harus ditawarkan oleh lembaga perbankan harus sesuai dengan ketentuan yang ada berdasar pada jenis bank itu sendiri, dalam artian bahwa jenis bank di sini akan sangat mempengaruhi jasa yang ditawarkan, sehingga dengan ini terdapat suatu ketentuan di mana terdapat jasa-jasa yang hanya bisa diberikan oleh Bank Umum, tetapi tidak oleh Bank Perkreditan Rakyat.

Hukum Perbankan di Indonesia merupakan bagian dari hukum nasional Indonesia, yaitu hukum yang mengatur mengenai masalah-masalah perbankan yang berlaku pada saat sekarang di Indonesia. Hukum perbankan adalah sekumpulan peraturan hukum yang mengatur kegiatan lembaga keuangan bank yang meliputi segala aspek, dilihat dari segi esensi dan eksistensinya, serta hubungannya dengan bidang kehidupan yang lain (Djumhana, 1996: 1). Sumber hukum adalah segala apa saja yang menimbulkan aturan yang mempunyai kekuatan yang bersifat memaksa, yakni aturan-aturan yang apabila dilanggar mengakibatkan sanksi yang tegas dan nyata (Kansil, 1989: 46). Sumber hukum formal dalam hukum perbankan (Djumhana, 1996: 7).

Berlatar belakang dari fungsi serta peranan dari lembaga keuangan bank sebagaimana telah tertulis di atas, maka dalam hubungannya dengan perspektif yuridis dari perbankan itu sendiri, hukum perbankan sebagai hukum modern yang mempunyai sifat dan fungsi instrumental yaitu bahwa hukum sebagai sarana perubahan melalui pembuatan peraturan perundang-undangan yang dijadikan media untuk menyalurkan kebijakan, yang dengan demikian diharapkan akan bisa menciptakan keadaan yang baru atau mengubah sesuatu yang sudah ada, maka hukum dalam dunia perbankan mempunyai peranan yang cukup besar untuk menciptakan kehidupan perbankan yang sehat sehingga akan membawa kepada 
kesejahteraan masyarakat nantinya (Djumhana, 1996: 19).

Arsitektur Perbankan Indonesia (API) merupakan banking architecture yang bukan saja diperlukan bagi kegiatan perbankan saja, tetapi juga sangat penting dalam sektor keuangan secara menyeluruh untuk mengetahui peta perbankan di masa mendatang (Sihabudin, 2005). Tujuan API yang mendasar adalah terciptanya suatu sistem perbankan nasional yang sehat, kuat, dan efisien guna menciptakan kestabilan sistem keuangan dalam rangka membantu mendorong pertumbuhan ekonomi nasional. API ini memiliki 6 (enam) pilar (tiang), yaitu:

a. Struktur perbankan yang sehat.

b. Sistem pengaturan yang efektif.

c. Sistem pengawasan yang independen dan efektif.

d. Industri perbankan yang kuat.

e. Infrastruktur pendukung yang mencukupi.

f. Perlindungan konsumen.

Berbagai pilar (enam pilar) untuk mencapai visi perbankan di kurun waktu ke depan tersebut akan dapat terlaksana jika kebijakan yang ada dituangkan dalam norma hukum yang berupa peraturan perundang-undangan sebagai kerangka kerjanya (frame work) dan sebagai alat perubahan kineja (as a tool of working engineering), yang diharapkan norma tersebut dapat berjalan dengan efektif. Keefektifan konsepsi sistem hukum (legal system) ini menurut Friedman (2009 :16) terdiri 3 (tiga) komponen, yaitu: structure of legal system, substance of legal system, and legal culture, yang dalam konsep di Indonesia lebih dirinci lagi menjadi 5 (lima) komponen, yakni: faktor hukum (normanya), faktor penegak hukum, faktor sarana atau fasilitas yang mendukung penegakan hukum, faktor masyarakat, dan faktor kebudayaan. Persoalan yang terjadi di dunia perbankan kita tampaknya lebih banyak disebabkan oleh: (i) pertama faktor kebijakan yang seringkali karena tuntutan pihak luar yang kadang-kadang tidak sesuai dengan kondisi riil kita dan bahkan sering berubah-ubah sehingga tidak ada kepastian hukum; (ii) kedua para fungsionaris atau pihak penegak norma sendiri yang seharusnya berfungsi mendukung bekerjanya sistem kenyataannya banyak yang tidak memberi teladan kepatuhan; (iii) ketiga faktor budaya kita yang kurang mendukung baik di kalangan aparat/fungsionaris/pelaku perbankan maupun masyarakat, sebagai contoh kejujuran, kepatuhan pada norma dan kebijakan seringkali diabaikan demi kepentingan diri sendiri atau kelompoknya.

Permasalahannya adalah apakah aspek hukum yang sudah ada maupun yang dirancang sudah menunjang konsep 6 (enam) pilar untuk tercapainya tujuan Arsitektur Perbankan Indonesia tersebut. Tentunya pembahasan ini diperlukan suatu kajian yang cukup mendalam dan membutuhkan ketelitian serta yang komprehensif agar perkembangan perbankan kita di masa mendatang benar-benar kuat dan terjadinya suatu kepastian melangkah untuk menunjang pembangunan dan perekonomian Indonesia.

Pembicaraan struktur perbankan ini seringkali mengarah pada jumlah lembaga perbankan yang ada serta jumlah permodalan yang dibutuhkan agar kehidupan dunia perbankan dapat berjalan dengan sehat dan kuat. Isu tentang jumlah bank ini merupakan permasalahan yang cukup menonjol dalam hal pembicaraan struktur perbankan, tetapi sebenarnya belum ada suatu konsep yang 
jelas berapa jumlah bank yang ideal dalam suatu negara. Kenyataan di Indonesia terjadinya krisis ekonomi pada tahun 1997 mengakibatkan runtuhnya beberapa lembaga perbankan, yang berarti indikasi kurang kuat dan kurang sehatnya lembaga perbankan kita. Awal krisis ekonomi mengakibatkan 16 bank runtuh. Untuk penyehatan perbankan yang ada dibentuklah lembaga khusus untuk menanganinya. Berdasarkan Keputusan Presiden Republik Indonesia Nomor 27 dan Keputusan Presiden Republik Indonesia Nomor 34 Tahun 1988, kemudian Peraturan Pemerintah Nomor 17 Tahun 1999, kemudian Peraturan Pemerintah Nomor 47 Tahun 2001 dibentuklah Badan Penyehatan Perbankan Nasional. Berdasarkan Peraturan Pemerintah Nomor 25 Tahun 1999 tentang Pencabutan Izin Usaha, Pembubaran dan Likuidasi Bank serta Peraturan Pemerintah Nomor 28 Tahun 1999 tentang Merger, Konsolidasi, dan Akuisisi Bank merupakan pijakan tindakan terhadap bank-bank bermasalah. Dengan dikeluarkan berbagai peraturan tersebut berdampak pada berkurangnya atau penutupan beberapa bank di Indonesia. Penutupan beberapa bank ini sebenarnya atas program dan rekomendasi International Monetary Fund (IMF), yang ternyata menimbulkan gejolak sosial dan social cost yang cukup banyak. Pada akhir tahun 2003 kita telah bertekad mengakhiri kerjasama dengan International Monetary Fund (IMF) di sektor ekonomi, tetapi bukan berarti Indonesia akan keluar dari keanggotaan resmi International Monetary Fund (IMF), melainkan ia tidak lagi berfungsi sebagai supervisi yang menentukan program-program ekonomi Indonesia. Kita tidak perlu khawatir tentang kondisi perbankan setelah ditinggal oleh International Monetary Fund (IMF), bahkan mudah-mudahan akan lebih baik dan lebih dewasa dalam menentukan kebijakan perekonomian kita sendiri.

Bank Indonesia (BI) dan Badan Penyehatan Perbankan Nasional dengan kewenangan yang dimiliki pada tahun 1999 mengumumkan berbagai keputusan dalam rangka penyehatan perbankan nasional berupa: 38 bank ditutup dalam status Bank Beku Operasional dan Bank Beku Kegiatan Usaha (BBO dan BBKU), 7 bank diambil alih atau bank take over (BTO), 9 bank diikutsertakan dalam program rekapitalisasi, selain itu terdapat juga beberapa bank yang melebur bergabung atau merger. Pada awal tahun 2003 bank yang ada berjumlah 138, kemudian menyusul lagi penutupan 2 (dua) bank dan ada lagi sebuah bank yang bermasalah. Dapat dikatakan, bahwa untuk mengatasi krisis perbankan tersebut kita melakukan kebijakan secara instan. Peraturan Pemerintah Nomor 25 Tahun 1999 tentang Pencabutan Izin Usaha, Pembubaran dan Likuidasi boleh jadi merupakan salah satu kebijakan yang bersifat instan tersebut. Ukuran yang dipakai sebagai pedoman untuk melihat suatu bank sehat atau tidak, meskipun harus ditinjau dari berbagai aspek, tetapi pada saat ini umumnya berpegang pada kondisi keuangan atau permodalan bank yang bersangkutan. Pelanggaran yang dilakukan sebagian besar bank tidak sehat ini yang paling menonjol adalah tidak terpenuhinya Capital Adequacy Ratio (CAR) atau Batas Minimum Modal Kerja (BMMK) dan Legal Lending Limit atau Batas Maksimum Pemberian Kredit (BMPK).

Di sisi lain beberapa bentuk hukum lembaga perbankan yang ada serta pengaturannya masih belum terjadi kesamaan. Hal ini juga disebabkan masih dimungkinkannya bentuk hukum yang beraneka ragam, yakni lembaga perbankan 
di Indonesia dapat berbentuk Perseroan Terbatas (PT), Perusahaan Daerah (PD) dan Koperasi. Oleh karena itu sekiranya dimungkinkan alangkah baiknya jika bentuk hukum perbankan diseragamkan hanya satu bentuk, yakni badan hukum yang berbentuk Perseroan Terbatas. Di bagian sebelumnya sudah disebutkan, bahwa suatu program atau rencana yang bagus sulit untuk berjalan secara efektif kalau tidak disertai dengan peraturannya. Peraturan ini dituangkan dalam norma, dan norma yang mempunyai kekuatan memaksa adalah norma hukum. Aspek law enforcement ini perlu perhatian yang cukup, sebab penegakan hukum inilah yang memberikan kepastian terciptanya kedisiplinan kegiatan perbankan nasional. Meskipun ada beberapa kekurangan dan kelemahan di bidang hukum perbankan kita, tetapi dengan perbaikan-perbaikan yang ada diharapkan akan semakin sempurna.

Melalui API, Bank Indonesia juga telah menetapkan berbagai program perbaikan dan peningkatan kualitas pengaturan dan pengawasan perbankan. Guna membuat peraturan perbankan, maka setiap peraturan akan dibuat berdasarkan pada penelitian (research-based) dan diupayakan selalu mengacu pada best practices serta berstandar internasional. Di samping itu pendekatan yang dilakukan bersifat market oriented, yakni dengan melibatkan kalangan praktisi perbankan dalam rangka proses penyusunan suatu peraturan. Persoalan yang perlu dipikirkan adalah peraturan-peraturan/ketentuan-ketentuan produk BI yang berupa Peraturan Bank Indonesia (PBI) pada jenjang hukum di Indonesia disetarakan dengan peraturan apa harus diperjelas, sehingga pada saat ada suatu ketidaksinkronan akan dapat dengan mudah ditentukan dasar untuk mengevaluasi dan memperbaikinya, bahkan kalau perlu peraturan BI merupakan suatu peraturan yang bersifat khusus (lex specialis), dan hal ini harus dipertegas pada susunan jenjang/kedudukan di peraturan perundang-undangan. Sebagaimana telah diungkapkan di atas, bahwa suatu norma/peraturan yang diterbitkan serta pengawasannya dapat berjalan atau tidak secara efektif hendaknya dilihat dari teori efektifitas tersebut di atas, sedangkan pengaruh yang terbesar adalah budaya manusianya, baik para pengawas maupun praktisi perbankannya.

\section{METODE PENELITIAN}

Dalam penelitian ini peneliti menggunakan metode penelitian Yuridis Normatif. Dalam konteks ini peneliti ingin mengkaji dan menganalisis beberapa instrumen hukum positif yang mendukung (support) terhadap pelaksanaan mekanisme penyelesaian sengketa melalui proses mediasi di sektor bisnis perbankan. Di samping meneliti instrumen hukum positif untuk melengkapi analisis juga menggunakan data pendukung berupa praktik mediasi perbankan yang dijalankan oleh Bank Indonesia dan beberapa bank. Sehingga berdasarkan pada proses analisis secara holistik dan komprehensif diharapkan mampu menawarkan sebuah solusi konkret mengenai gagasan konseptual pembentukan lembaga mediasi perbankan independen.

Sedangkan metode pendekatan dalam penelitian ini menggunakan metode pendekatan perundang-undangan (Statuta Approach) dan metode pendekatan konsep (Conseptual Approach) yaitu menawarkan solusi mengenai konsep 
pembentukan dan mekanisme pelaksanaan mediasi perbankan yang efektif dan efisien. Jenis data dalam penelitian ini terdiri dari:

a) Bahan Hukum Primer yang terdiri dari:

1) Amandemen ke IV Undang-Undang Dasar 1945.

2) Undang-Undang Nomor 23 Tahun 1999 tentang Bank Indonesia.

3) Undang-Undang Nomor 7 Tahun 1992 tentang Perbankan.

4) Undang-Undang Nomor 10 Tahun 1998 tentang Perubahan atas UndangUndang Nomor 7 Tahun 1992 tentang Perbankan.

5) Undang-Undang Nomor 30 Tahun 1999 tentang Arbitrase dan Alternatif Penyelesaian Sengketa.

6) Peraturan Bank Indonesia Nomor 8/5/PBI/2006 tentang Mediasi Perbankan.

7) Peraturan Bank Indonesia Nomor 10/1/PBI/2008 tentang Perubahan atas Peraturan Bank Indonesia Nomor 8/5/PBI/2006 tentang Mediasi Perbankan.

8) Peraturan Bank Indonesia Nomor 7/7/PBI/2005 tentang Penyelesaian Pengaduan Nasabah.

9) Peraturan Bank Indonesia Nomor 10/10/PBI/2008 tentang Perubahan atas Peraturan Bank Indonesia Nomor 7/7/PBI/2005 tentang Penyelesaian Pengaduan Nasabah.

10) Peraturan Mahkamah Agung (PERMA) Nomor 02 Tahun 2003 tentang Prosedur Mediasi di Pengadilan Mahkamah Agung Republik Indonesia.

b) Bahan Hukum Sekunder

Bahan hukum sekunder terdiri dari buku literatur yang relevan dengan substansi penelitian, artikel, jurnal, hasil penelitian sebelumnya, penelusuran di Internet, konsultasi dengan dosen pembimbing, wawancara dengan stake holder terkait dengan materi penelitian.

Teknik memperoleh data dilakukan dengan cara mengunjungi unit perpustakaan dan penelusuran melalui internet. Teknik Analisis data dalam penelitian ini menggunakan teknik analisis Deskriptif Analitis yaitu mengkaji, mendiskripsikan fakta, dan menganalisis instrumen hukum positif ke dalam kerangka sistematis penelitian. Berdasarkan analisis tersebut maka ditarik simpulan sebagai pedoman kerangka konseptual mengenai pembentukan dan pelaksanaan mekanisme mediasi bentuk penyelesaian sengketa antara bank dan nasabah yang efektif dan efisien.

\section{HASIL PENELITIAN DAN PEMBAHASAN}

\section{Landasan Urgensi Pembentukan Lembaga Mediasi Perbankan Independen}

Arsitektur Perbankan Indonesia merupakan suatu kerangka dasar sistem perbankan Indonesia yang bersifat menyeluruh dan memberikan arah, bentuk, dan tatanan industri perbankan untuk rentang waktu lima sampai sepuluh tahun ke depan. Arah kebijakan pengembangan industri perbankan di masa mendatang yang dirumuskan dalam Arsitektur Perbankan Indonesia dilandasi oleh visi mencapai suatu sistem perbankan yang sehat, kuat, dan efisien guna menciptakan kestabilan sistem keuangan dalam rangka membantu mendorong pertumbuhan ekonomi nasional, mengingat bahwa perbankan Indonesia dalam menjalankan 
fungsinya berasaskan prinsip kehati-hatian. Fungsi utama perbankan Indonesia adalah sebagai penghimpun dan penyalur dana masyarakat serta bertujuan untuk menunjang pelaksanaan pembangunan nasional dalam rangka meningkatkan pemerataan pembangunan dan hasil-hasilnya, pertumbuhan ekonomi, dan stabilitas nasional, ke arah peningkatan taraf hidup rakyat banyak. Oleh sebab itu yang menjadi alasan pentingnya pelaksanaan mediasi perbankan antara lain:

\section{a. Alasan Ekonomis}

Pelaksanaan mediasi merupakan bentuk penyelesaian yang besifat non litigasi. Sebagai bentuk alternatif mediasi dalam tataran pelaksanaan memiliki keunggulan dan kelemahan. Penyelesaian Sengketa Alternatif (Alternative Dispute Resolution) memiliki kelebihan dibandingkan dengan penyelesaian sengketa melalui lembaga peradilan, kelebihanya yaitu:

1) Kerahasiannya dijamin oleh para pihak yang bersengketa.

2) Kelambatan yang dikarenakan hal prosedur dan administrasi dapat dihindari.

3) Para pihak bisa memilih arbiter yang menurut keyakinan mereka mempunyai pengetahuan, pengalaman, dan latar belakang yang memadai mengenai masalah yang disengketakan, jujur, serta adil.

4) Para pihak dapat menentukan pilihan hukum untuk menyelesaikan masalah, proses dan tempat penyelenggaraan arbitrase.

5) Putusan arbitrase merupakan putusan yang memikat para pihak dengan cara atau prosedur yang sederhana dan mudah dilaksanakan.

Meskipun demikian, Penyelesaian Sengketa Alternatif yang memiliki banyak keunggulan, terdapat pula kelemahan-kelemahan karena mekanismenya yang rentan terhadap kondisi di negara Indonesia. Kelemahan-kelemahan itu antara lain:

1) Penyelesaian Sengketa Alternatif belum begitu dikenal baik oleh masyarakat awam, masyarakat bisnis, maupun masyarakat akademis. Contohnya masyarakat masih belum mengetahui lembaga-lembaga BANI, BAMUI, P3BI.

2) Masyarakat masih belum percaya atau ragu terhadap Penyelesaian Sengketa Alternatif. Hal ini nampak pada minimnya penyelesaian perkara yang bisa diselesaikan oleh lembaga Penyelesaian Sengketa Alternatif.

3) Lembaga Penyelesaian Sengketa Alternatif tidak mempunyai wewenang melakukan eksekusi putusanya. Meskipun, keputusan arbitrase itu bersifat mengikat, dalam pelaksanaanya harus melalui "fiat eksekusi" pengadilan.

4) Kurangnya kepatuhan para pihak terhadap hasil-hasil penyelesaian yang dicapai dalam Penyelesaian Sengketa Alternatif, sehingga mereka sering mengingkari dengan berbagai cara baik dengan mengulur waktu, perlawanan, gugatan pembatalan, dan lain- lain.

5) Kurangnya kesediaan para pihak untuk melepas sebagian hak-haknya. Penyelesaian dengan litigasi lebih sering diterapkan, sehingga membuat para pihak berpikir win-lose solution, bukan win-win solution yang diharapkan oleh Penyelesaian Sengketa Alternatif.

6) Para pihak kurang memegang etika bisnis, sebagai suatu mekanisme extra judicial, Penyelesaian Sengketa Alternatif hanya dapat bertumpu di atas etika bisnis, seperti kewajaran dan kejujuran. 
Dengan demikian, mediasi adalah cara penyelesaian sengketa di luar pengadilan melalui perundingan yang melibatkan pihak ketiga yang bersifat netral (non intervensi) dan tidak berpihak (impartial) serta diterima kehadirannya oleh pihak-pihak yang bersengketa. Pihak ketiga ini sebagai mediator yang membantu pihak-pihak yang bersengketa dalam menyelesaikan masalah dengan harapan mempertemukan keinginan dan kepentingan dalam menyelesaikan masalah yang dihadapi para pihak, tetapi tidak berwenang untuk mengambil keputusan, yang berhak mengambil keputusan adalah pihak yang bersengketa.

Berdasarkan ketentuan pasal 6 ayat (3) Undang-Undang Nomor 30 Tahun 1999, disebutkan bahwa dalam hal sengketa atau beda pendapat tidak dapat diselesaikan, maka atas kesepakatan tertulis para pihak, sengketa atau beda pendapat diselesaikan melalui bantuan seseorang atau lebih pada penasihat ahli maupun melalui seorang mediator. Kesepakatan penyelesaian sengketa atau beda pendapat secara tertulis adalah final dan mengikat bagi para pihak untuk dilaksanakan dengan itikad baik. Kesepakatan tertulis wajib didaftarkan di Pengadilan Negeri dalam waktu paling lama 30 (tiga puluh) hari terhitung sejak penandatanganan, dan wajib dilaksanakan dalam waktu lama 30 (tiga puluh) hari sejak pendaftaran.

Pada dasarnya karakteristik penyelesaian sengketa melalui mediasi adalah sebagai berikut:

1) Mediasi adalah proses penyelesaian sengketa di luar pengadilan berdasarkan perundingan.

2) Mediator terlibat dan diterima oleh para pihak yang bersengketa di dalam perundingan

3) Mediator bertugas membantu para pihak yang bersengketa untuk mencari penyelesaian

4) Mediator bersifat pasif dan hanya berfungsi sebagai fasilitator dari para pihak yang bersengketa, sehingga tidak terlibat dalam menyusun dan merumuskan rancangan kesepakatan.

5) Mediator tidak mempunyai wewenang membuat keputusan selama perundingan berlangsung.

6) Tujuan mediasi adalah mencapai atau menghasilkan kesepakatan yang dapat diterima pihak-pihak yang bersengketa guna mengakhiri sengketa.

\section{b. Alasan Yuridis}

Secara yuridis pelaksanaan mediasi perbankan merupakan bagian dari pembangunan sektor perekonomian nasional. Dasar konstitusional pelaksanaan perekonomian yang berbasis pada kekeluargaan dijamin di dalam pasal 33 ayat (1) Undang-Undang Dasar 1945 yang berbunyi, "Perekonomian disusun berdasarkan atas asas kekeluargaan”. Di samping itu dasar pelaksanaan mediasi perbankan oleh bank Indonesia selaku otoritas perbankan telah diatur di dalam Peraturan Bank Indonesia Nomor 8/5/PBI/2006 jo. Peraturan Bank Indonesia Nomor 10/1/PBI/2008 tentang Perubahan atas Peraturan Bank Indonesia Nomor 8/5/PBI/2006 tentang Mediasi Perbankan. Pembentukan lembaga mediasi perbankan oleh Asosiasi Perbankan merupakan wujud itikad baik dari pengusaha perbankan untuk melakukan sinergitas dengan Bank Indonesia. Sehingga dalam 
hal ini tidak ada efek anggaran negara yang dirugikan akibat ketimpangan dalam pelaksanaan mediasi yang selama ini dibebankan kepada Bank Indonesia.

\section{Solusi Konkret Mengenai Pembentukan Lembaga Mediasi Perbankan Independen oleh Asosiasi Perbankan Sebagai Upaya Strategis Mewujudkan Pilar Arsitektur Perbankan Indonesia (API)}

Asosiasi Perbankan yang membentuk lembaga mediasi perbankan independen dapat terdiri dari gabungan asosiasi perbankan untuk menjaga indepedensinya, selain dapat pula dilakukan perekrutan dari kalangan bankir. Untuk mencapai tujuan tersebut pendekatan yang dilakukan dengan menerapkan:

1. Kebijakan memberikan keleluasaan berusaha (deregulasi).

2. Kebijakan prinsip kehati-hatian bank (prudential banking).

3. Pengawasan bank yang mendorong bank untuk melaksanakan secara konsisten ketentuan intern yang dibuat sendiri (self regulatory banking) dalam melaksanakan kegiatan operasionalnya dengan tetap mengacu kepada prinsip kehati-hatian.

Bank Indonesia (BI) harus mewajibkan seluruh bank untuk menjadi anggota dari lembaga mediasi perbankan. Agar mempunyai kekuatan hukum mengikat, maka Bank Indonesia perlu membuat Peraturan Bank Indonesia tentang kewajiban bank menjadi anggota lembaga mediasi. Kemudian untuk menjaga kualitas dari lembaga mediasi perbankan ini, maka Bank Indonesia dapat memberikan akreditasi pada lembaga mediasi perbankan Indonesia tersebut. Lembaga mediasi mempunyai kewajiban melaporkan secara berkala pada Bank Indonesia mengenai sengketa yang pernah dimediasikan. Kemudian dari laporan tersebut Bank Indonesia dapat mengevaluasi kinerja dari lembaga mediasi perbankan independen tersebut dan memberikan akreditasinya. Dalam lembaga mediasi ini harus ada mediator independen yang dapat memberikan saran sesuai dengan profesinya masing-masing. Dengan demikian pembentukan lembaga mediasi perbankan diharapkan dapat memberikan nilai positif baik bagi nasabah maupun bank, seperti terciptanya kepastian penyelesaian sengketa antara nasabah dengan bank. Mediasi perbankan ini juga akan mendorong terciptanya keseimbangan hubungan antara posisi nasabah dengan bank.

Selama ini sebelum terbentuknya lembaga mediasi perbankan independen, mediasi perbankan dijalankan oleh Bank Indonesia. Bank Indonesia telah mempunyai sarana dan prasarana yang memadai, pendanaan yang cukup dan sumber daya berupa mediator yang memperoleh pelatihan dan sertifikasi sebagai mediator dan mempunyai latar belakang perbankan. Oleh sebab itu Bank Indonesia selaku otoritas perbankan sudah selayaknya mendorong terbentuknya lembaga mediasi oleh Asosiasi Perbankan sebagai langkah untuk mengeliminasi beban anggaran negara di sektor perbankan.

\section{SIMPULAN}

Urgensi pembentukan lembaga mediasi perbankan dalam upaya mewujudkan Arsitektur Perbankan Independen (API) dilandasi oleh dua aspek yaitu aspek ekonomis dan aspek yuridis. Pembentukan lembaga mediasi 
perbankan harus didorong oleh Asosiasi Perbankan sehingga tidak ada akses kerugian negara yang dibebankan dalam rangka penyelesaian sengketa antara pengusaha perbankan dan nasabah yang dimediatori oleh Bank Indonesia.

\section{SARAN}

Bank Indonesia sebagai otoritas perbankan hendaknya dapat mendorong Asosiasi Perbankan untuk segera mendirikan lembaga mediasi perbankan independen yang profesional, akuntabel, dan transparan. Di samping itu mediasi sebagai salah satu bentuk alternatif penyelesaian sengketa non litigasi dapat menjadi upaya preventif dalam rangka memperkuat sektor perbankan di bidang perlindungan konsumen sebagai salah satu pilar tegaknya Arsitektur Perbankan Indonesia (API).

\section{DAFTAR PUSTAKA}

Anonymous. 2007. Mediasi Perbankan, Alternatif Penyelesaian Sengketa BankNasabah. diakses dari http://www.indopos.co.id pada tanggal 20 November 2007.

Bank Indonesia. diakses dari http://www.hukumonline.com.

Departemen P dan K. 1989. Kamus Besar Bahasa Indonesia. Jakarta: Balai Pustaka.

Djumhana, Muhamad. 1996. Rahasia Bank (Ketentuan dan Penerapannya) di Indonesia. Bandung: PT Citra Aditya Bakti.

Friedman, Lawrence Meir. 2009. Sistem Hukum: Perspektif Ilmu Sosial. Diterjemahkan dari buku The Legal System: A Social Science Perspective. Bandung: Nusa Media.

Hadad, D. Muliaman. 2004. Menanti Mediator Bank-Nasabah. (BEI News edisi 23 tahun V, November-Desember 2004). diakses dari http://www.bi.go.id pada tanggal 20 November 2007.

Kansil, 1989. Pengantar Ilmu Hukum dan Tata Hukum Indonesia. Jakarta: Balai Pustaka.

Keputusan Presiden Republik Indonesia Nomor 27 Tahun 1998 tentang Pembentukan Badan Penyehatan Perbankan Nasional.

Keputusan Presiden Republik Indonesia Nomor 34 Tahun 1998 tentang Tugas dan Kewenangan Badan Penyehatan Perbankan Nasional.

Naja, Daeng. 2006. Hukum Kredit dan Bank Garansi (The Bankers Hand Book). Bandung: PT Citra Aditya Bakti.

Peraturan Bank Indonesia Nomor 7/7/PBI/2005 tentang Penyelesaian Pengaduan Nasabah. 
Peraturan Bank Indonesia Nomor 8/5/PBI/2006 tentang Mediasi Perbankan.

Peraturan Bank Indonesia Nomor 10/1/PBI/2008 tentang Perubahan atas Peraturan Bank Indonesia Nomor 8/5/PBI/2006 tentang Mediasi Perbankan.

Peraturan Bank Indonesia Nomor 10/10/PBI/2008 tentang Perubahan atas Peraturan Bank Indonesia Nomor 7/7/PBI/2005 tentang Penyelesaian Pengaduan Nasabah.

Peraturan Mahkamah Agung (PERMA) No. 2 Tahun 2003 tentang Prosedur Mediasi di Pengadilan Mahkamah Agung Republik Indonesia.

Peraturan Pemerintah Republik Indonesia Nomor 17 Tahun 1999 tentang Badan Penyehatan Perbankan Nasional.

Peraturan Pemerintah Republik Indonesia Nomor 25 Tahun 1999 tentang Pencabutan Izin Usaha, Pembubaran dan Likuidasi Bank.

Peraturan Pemerintah Republik Indonesia Nomor 28 Tahun 1999 tentang Merger, Konsolidasi dan Akuisisi Bank.

Peraturan Pemerintah Nomor 47 Tahun 2001 tentang Perubahan Keempat Atas Peraturan Pemerintah Nomor 17 Tahun 1999 Tentang Badan Penyehatan Perbankan Nasional.

Rachagan, S. Sothi. 2008. Alternatif Penyelesaian Sengketa Konsumen Butuh Progresivitas. diakses dari http://www.hukumonline.com pada tanggal 6 November 2009.

Ruru, Bacelius. 2007. Penyelesaian Sengketa Melalui Mekanisme di Luar Pengadilan. diakses dari http://www.bapmi.org pada tanggal 3 November 2007.

Sihabudin, 2005. Tinjauan Hukum dan Penegakannya demi Terlaksananya Arsitektur Perbankan Indonesia (API). Teaching Material Fakultas Hukum Universitas Brawijaya Malang.

Simorangkir, O. P.. 1986. Dasar-dasar Perbankan. Jakarta: Raja Grafindo Persada.

Sudiarto dan Zaeni Asyhadie. 2004. Mengenal Arbitrase Salah Satu Alternatif Penyelesaian Sengketa Bisnis. Jakarta: PT RajaGrafindo Persada.

Sumarni, Murti dan John Soeprihanto. 1998. Pengantar Bisnis (Dasar Ekonomi Perusahaan). Yogyakarta: Liberty.

Sutiyoso, Bambang. 2008. Hukum Arbitrase dan Alternatif Penyelesaian Sengketa. Yogyakarta: Gamamedia.

Undang-Undang Dasar 1945. Amandemen ke IV. 
Undang-Undang Nomor7 Tahun 1992 tentang Perbankan.

Undang-Undang Nomor 10 Tahun 1998 tentang Perubahan atas Undang-Undang Nomor 7 Tahun 1992 tentang Perbankan.

Undang-Undang Nomor 23 Tahun 1999 tentang Bank Indonesia.

Undang-Undang Nomor 30 Tahun 1999 tentang Arbitrase dan Alternatif Penyelesaian Sengketa.

www.jatim.go.id. Pengaduan pada Perbankan Meningkat. 